\title{
The Effect of Computer- assisted Language Learning on Improving EFL Learners' Pronunciation Ability
}

\author{
Farima Talebi ${ }^{1, *} \&$ Nasrin Teimoury ${ }^{2}$ \\ ${ }^{1}$ Department of English, Hakim Sabzevari University, Iran \\ ${ }^{2}$ Department of English, Islamic Azad University, Torbate Heidarieh, Iran \\ *Corresponding author: Department of English, Hakim Sabzevari University, Iran \\ E-mail: Farimah_1984@yahoo.com
}

Received: April 5, 2013

doi:10.5430/wjel.v3n2p52

\author{
Accepted: May 8, $2013 \quad$ Online Published: Jun 22, 2013 \\ URL: http://dx.doi.org/10.5430/wjel.v3n2p52
}

\begin{abstract}
Computer aided language learning having replaced the traditional paradigms has been acknowledged by many educators, and also began to become a unique opportunities in an educational context (Arias, Yoma \& Vivanco, 2010). This paper tries to show the impacts of Computer Assisted Language Learning (CALL) on Iranian female students' pronunciation skills. 60 students randomly selected from NemoonehVakili junior high school were divided into control and experimental groups. The administration of a pronunciation test showed that two groups were homogeneous in terms of their pronunciation skills at the entry level. While both groups had the same instructor during 8 sessions, only the experimental group received the materials by using computer. The performance of the experimental group on pronunciation test held at the end of the course showed that the mean score of this group was significantly higher than the control group. Hence, the students' learning based on CALL can increase the motivation and interest of learning among the learners and have a profound impact on the students' achievement of pronunciation.
\end{abstract}

Keywords: computer assisted language learning (CALL); pronunciation skill

\section{Introduction}

With the pervasive influence of technology on education, relationship between language ability and computer use have gained more attention during the last decade. Computer Assisted Language Learning (CALL) is often perceived as an approach to language teaching and learning in which the computer is used as an aid to the presentation, reinforcement, and assessment of material going to be learned (Rahimi \& Yadollahi, 2011).

As Hashemi and Aziznezhad (2011) stated one of the big advantages of CALL is that it helps to generate autonomous learners. Another merit is that it has a new crucial role in teaching material. In other words, using CALL in a learning pedagogy reinforces current practices and promotes curriculum renewal. They also believed that before applying computer in a learning pedagogy, teachers should consider many important factors. First of all, they should evaluate the learners' computer skills to make them aware of the basic computer skills. The second factor is the learners' language level and navigation on the web. As far as most of the web sites are in English, the students require high knowledge of the English language. The last but not the least factor is some technical issues which should be taken into account such as, access to network environment, use of modern equipment and software, awareness of basic internet technology, and potential problems by teachers.

Similarly, Ghasemi, Hashemi, and Barani (2011) held the idea that learning via technology has many benefits. For example, through using internet, the learners can be provided current and up-to-date data and vast amount of information that can be retrieved easily and quickly. Computer, also, can serve a variety of uses for language teaching. It can be a tool for reading, writing, and doing researches, a stimulus for engaging students in authentic conversation and interaction, and a teacher practicing different drills and skills. More importantly, integration of computer-based materials into the educational environment transforms the students from passive recipients into active participants.

Regarding the significance of computer in educational contexts, Sophocleous (2012) explored the importance of the 
use of technology in language teacher training course. To meet their aims, the researcher provided a CALL course for 11 students as part of their Bachelor of Arts in English language and Literature at the University of Nicosia, Cyprus. All CALL courses were in the language laboratory. At the beginning, the students were helped to set up a wiki used a delivery and management tool to serve 3 purposes. The first one: it provided students with the use of new technology based on sound second language teaching pedagogy. The second one: it enabled students to keep a record of their work and learning for reflection. The last one: it gave them an opportunity to create a site where they had enough online teaching materials to motivate them to use technology. For a semester students worked in language laboratory and at home with the use of wiki or similar soft ware. At the end of the course, the students were asked to complete an evaluation questionnaire. The results of study shows that all students found wiki very useful and they said they would continue using wiki and other soft wares if they teach.

The study done by Razavi and Ketabi (2011) set out to investigate the differences between 2 types of instruction materials- websites vs. textbooks- and their effects on the learners' knowledge of certain grammatical rules. To reach their aims, the researcher chose 120 Iranian intermediate EFL learners and put them into 3 groups: text-book group, website group, and control group. After giving a pre-test to all learners, the instructor used two grammar teaching text-books to teach learners in text-book group. While, for those in website group the same grammatical rules were taught on line via teaching websites. After the treatment phase, a post-test was administered to measure the gains. On the whole the findings of this study manifested that websites, as a new medium for instruction, can increase learners' motivation and improve their performance. In other words, the integration of web-based materials in language learning classrooms can enhance learners' mastery of English grammar.

In a similar vein, Al-Mansour and Al-Shorma (2012) carried out a study in which 60 university students were randomly selected and assigned to experimental and control groups. The experimental group used the computers alongside the traditional method and the other group used the traditional method alone. Both groups were subjected to a pretest immediately before starting the treatment and the same test was administered as a posttest immediately after it. Data collected from this study indicated that students taught through computer assisted language instruction showed better achievement than those who were taught through the traditional method alone.

In a recent study, Rahimi and Yadollahi (2011) investigated the relationship between attitudes toward computer-assisted language learning among 130 female students of high school. A CALL questionnaire turning out students' attitude towards computer-assisted language learning was used. Based on the results of this study, Iranian female students showed positive attitudes toward CALL. The truth of the matter is here that individuals' attitude can impact on their behaviors directly or indirectly. As a result of the attitude-behavior relationship, a positive attitude toward computer-assisted learning brings about using computer and technology in the context of learning. Vice versa, it has been found that a negative attitude may lead to computer resistance.

However, the findings of study done by Rahimi and Hosseini (2011) declared that students had strong negative attitudes towards using computer-assisted language learning alone; they did not believe that computer can take the place of traditional teaching. This shows that Iranian students do not agree with the replacement of the traditional methods with computer-based learning and they prefer mixed learning.

To have a more comprehensive outlook on the effects of computer assisted language learning (CALL), Barani (2011) illustrated the effects of computer language learning on listening skills. To reach the aim of study, the researcher chose 60 Iranian EFL learners and assigned them to experimental and control groups randomly. During 20 session instruction, the researcher presented and practiced all listening activities to the subjects in the control group. However, throughout the same period, he presented and practiced all these listening activities through CALL to the experimental group. The finding of this article demonstrated that computer assisted language learning has a significant impact on the listening skills. The data showed that users of computer outperformed nonusers in a listening test.

Providing more insights into the merits of computer in learning process, Abouseileek (2011) investigated the learners' communicative skills achievement in computer-based environments. 216 undergraduate general English language students were divided into cooperative groups in which the students in experimental group used computer-based instruction. The findings revealed that computer- based learning reduced the learners' anxiety from face-to-face debate, so it was very useful in developing the communication skills of foreign language learners.

The study by Marzban (2011) explored the effects of CALL on reading comprehension. In this study 60 Iranian female students were randomly assigned to experimental and control groups. One group used CALL for reading comprehension and another group was taught in the traditional way. As a result of this research, the use of computer assisted techniques can improve student's learning comprehension. In a similar study, Liu, chen, and Chang (2010) 
investigated the impacts of a computer-assisted concept mapping learning strategy on EFL learners' English reading comprehension. The findings showed that concept mapping reading strategy had an affective influence on learners' ability of reading comprehension and increased the learner's confidence in learning English reading.

Furthermore, Hegelheimor and Tower (2004) investigated the relationship between CALL and non-CALL environments to find what the learners do through CALL activities and explore their reactions in a CALL program in an authentic setting. Data collected from 94 university students manifested positive effect on the students' proficiency through using CALL and various options provided by the software.

There has been a large body of research addressing the effects of computer assisted language learning from various perspectives (Rahimi \& Yadollahi, 2011; Abouseileek, 2011; Marzban, 2011). Few numbers of studies, however, investigated the effects of computer learning on pronunciation skills (Arias, Yoma \& Vivanco, 2010); therefore, the present study addresses the following question:

1. Is there any significant difference between the mean scores of the group taught using CALL-based methods and the group taught using traditional methods?

In view of the above question, the present study tries to provide empirical supports for the following hypothesis:

HO1. There is not any significant difference between the mean scores of the group taught using CALL-based methods and the group taught using traditional methods.

\section{Methodology}

\subsection{Participants}

Sample population in this study was selected of 60 Iranian female students studying in grade 2 at Nemooneh Vakili junior high school in Neishabour. The average age of students was 13 . The participants were randomly divided into two experimental and control groups. Each group was consisted of30 students and their mother tongue was Persian. Both experimental and control group classes were held 2 sessions (one hour and a half) per week lasting for 5 weeks. Both groups had no experience in computer learning, and no distinction was made between them . The teacher was the same for the control and experimental groups. The experimental group accessed to the computer lab at school and the control group never used computer in their learning process.

\subsection{Instrument}

In order to address the research question the researcher utilizes the following instrument:

\subsubsection{Pronunciation Test}

A test consisting 60 words from English Pronunciation in use book (Jonathan Mark, 2007) was given to the experimental and control groups at the beginning and end of the course. Each individual learner was required to read the words loudly, and the teacher recorded their voices. This test was considered to measure the subjects' pronunciation skills before and after implementation of the treatment.

\subsection{Procedure}

The process of data collection started in December (2012) and continued until January (2013). At the first step, the researcher assigned the participants into experimental and control groups. The pronunciation test as a pretest was administered and all the participants were interviewed individually to ensure that there was no significant difference between two groups in terms of pronunciation skills.

During one-month course, participants in the experimental group took part in eight sessions in which they practice pronunciation of English vocabularies through computer. Simultaneously, the participants in the control group applied the traditional method for learning the pronunciation of the words and never used computer. Each instructional session lasted for 90 minutes from 7:30 to 9 for the experimental group and for the control group from 9:15 to 10:45 in the morning on Saturdays and Mondays.

At the end of the course, both groups were interviewed again and their pronunciation skill was assessed through pronunciation test as a posttest.

\section{Result}

Table 1 presents the descriptive statistics and independent sample t-test analysis of pronunciation test held as a 
pretest. As it can be clearly seen, the mean score of the experimental group (16.40) is higher than the control group (15.70). However, the independent sample t-test did not show any significant difference in the mean scores of the control and experimental groups on the pronunciation test $(\mathrm{t}=1.76, \mathrm{df}=58, \mathrm{p}>.05)$; thus, ensured the researchers of the homogeneity of both experimental and control groups in terms of their pronunciation skills at the entry level.

Table 1: The Descriptive Statistics and Independent Sample t-test Analysis of Pronunciation Test Held as a Pretest

\begin{tabular}{lllllllll}
\hline & Group & N & Mean & $\begin{array}{l}\text { Std. } \\
\text { Deviation }\end{array}$ & $\begin{array}{l}\text { Std. Error } \\
\text { Mean }\end{array}$ & T & Df & $\boldsymbol{P}$ \\
\hline Pretest & Control & 30 & 15.70 & 1.55 & .28 & 1.76 & 58 & .084 \\
& experimental & 30 & 16.40 & 1.52 & .27 & 1.76 & \\
\hline
\end{tabular}

Table 2 presents the results of paired sample t-test run to compare the performance of the control and experimental groups separately on the pronunciation pretest and posttest. According to this table, there was a significant difference between the mean scores on pronunciation pretest and posttest of the experimental group $(\mathrm{df}=29, \mathrm{t}=-13.95, \mathrm{p}<0.05)$, but there was no significant difference between the mean scores on pronunciation pretest and posttest of the control group $(\mathrm{df}=29, \mathrm{t}=-1.79, \mathrm{p}<0.08)$. These results revealed that only participants in the experimental group taking part in computer assisted learning course improved regarding their pronunciation skills.

Table 2: The Descriptive Statistics and Paired Sample t-test Analysis of Pronunciation Test Held as a Pretest and Posttest

\begin{tabular}{lccclllll}
\hline & Group & N & Mean & $\begin{array}{l}\text { Std. } \\
\text { Deviation }\end{array}$ & $\begin{array}{l}\text { Std. Error } \\
\text { Mean }\end{array}$ & T & Df & $\boldsymbol{P}$ \\
\hline pretest & Control & 30 & 15.70 & 1.55 & .28 & -1.79 & 29 & .08 \\
posttest & & & 16.30 & 2 & .36 & & & \\
pretest & Experimental & 30 & 16.40 & 1.52 & .27 & -13.95 & 29 & .000 \\
posttest & & & 19.03 & 1.24 & .22 & & & \\
\hline
\end{tabular}

Table 3 presents the descriptive statistics and independent sample t-test analysis of pronunciation test held as a posttest. As it can be seen, the mean score of the experimental group (19.03) is higher than the control group (16.30). Also, the independent sample t-test indicated that the experimental group performed significantly higher than the control group on the pronunciation test $(\mathrm{t}=6.34, \mathrm{df}=58, \mathrm{p}<.05)$. This means that the very implementation of computer assisted language learning helped the experimental group pronounce the English words significantly better than the control group; thus, the hypothesis that There is not any significant difference between the mean scores of the group taught using CALL-based methods and the group taught using traditional methods disconfirmed.

Table 3: The Descriptive Statistics and Independent Sample t-test Analysis of Pronunciation Test Held as a Posttest

\begin{tabular}{lllllllll}
\hline & Group & N & Mean & $\begin{array}{l}\text { Std. } \\
\text { Deviation }\end{array}$ & $\begin{array}{l}\text { Std. Error } \\
\text { Mean }\end{array}$ & T & Df & $\boldsymbol{P}$ \\
\hline posttest & Control & 30 & 16.30 & 2 & .36 & 6.34 & 58 & .000 \\
& Experimental & 30 & 19.03 & 1.24 & .22 & & & \\
\hline
\end{tabular}

\section{Conclusion}

The rapid growth of computer, a new technology in modern era, has caught the attention of all educators in different fields, especially language teachers. It is worth noting that many language teachers and learners use computer-based materials, attractive to and beneficial for learners, as a routine part of language learning opportunities (Jamieson \& Chapelle, 2010). As numerous websites containing plenty of foreign language learning materials and software have been activated during last decade, not only teachers but also learners are provided with rich resources of educational equipments (Uzun, 202).

The purpose of the current study was to examine the effects of Computer Assisted Language Learning (CALL) on Iranian language learners' pronunciation skills. Findings from this study indicated that integrating computer-based materials in a classroom had significant effect on the students' pronunciation skills. Prior to the treatment, the independent-sample t-test was administered to find out any significant difference in pre-test mean scores between students in experimental and control group. The findings revealed that both groups were equal $(p>0.05)$ in their performances at the beginning of the course. After the treatment, the independent sample t-test was done to find out any significant difference in pronunciation post-test mean scores between students in both groups. The findings indicated that students in experimental group showed significant $(\mathrm{p}<0.05)$ improvement in their pronunciation compared with the students in control group. This study came to a conclusion that CALL can contribute to the 
improvement of the students' pronunciation skills.

The findings of this study nearly reflect the results gained by Al-Mansour and Al-Shorma (2012) asserting that using computer-assisted materials alongside the traditional method has a positive effect on the students' achievement. These findings are also in line with the results gained by Razavi and Ketabi (2011) who conducted the integration of web-based materials in language learning classrooms can motivate the learners and improve their performance.

The findings of this study will be highly invaluable for teacher, material developers and instructors to consider the usefulness of on line instructional materials, and invest more in designing and applying such materials.

\section{References}

AbuSeileek, A.F. (2011). The effect of computer- assisted cooperative learning methods and group size on the EFL learner's achievement in communication skills. Computer and Education, 58, 231-239. http://dx.doi.org/10.1016/j.compedu.2011.07.011

Al-Mansour, N. S., \& Al-Shorman, R. A. (2012). The effect of computer assisted-instruction on Saudi university student's learning of English. Journal of King Saud University-Languages and Translation, 24, 51-56. http://dx.doi.org/10.1016/j.jksult.2009.10.001

Arias, J. P., Yoma, N. B., \& Vivanco, H. (2010). Automatic intonation assessment for computer aided language learning. Speech communication, 52, 254-267. http://dx.doi.org/10.1016/j.specom.2009.11.001

Barani, G. (2011). The relationship between computer assisted language learning (CALL) and listening skill of Iranian EFL learners. Procedia Social and Behavioral Sciences, 15, 4059-4063. http://dx.doi.org/10.1016/j.sbspro.2011.04.414

Ghasemi, B., Hashemi, M., \& Haghighi Bardine, S. (2011). The capabilities of computers for language learning. Procedia-Social and Behavioral Sciences, 58, 28-52.

Hashemi, M., \& Azizinezhad, M. (2011). Computer Assisted Language Learning Freedom or Submission to $\begin{array}{lllll}\text { Machines? } & \text { Procedia-Social and }\end{array}$ http://dx.doi.org/10.1016/j.sbspro.2011.11.152

Hegelheimor, V., \& Tower, D. (2004). Using CALL in the classroom: Analyzing student interactions in an authentic classroom. System, 32, 185-205. http://dx.doi.org/10.1016/j.system.2003.11.007

Jamieson, J., \& Chapelle, C.A. (2010). Evaluating CALL use across multiple contexts. System, 38, 357-369. http://dx.doi.org/10.1016/j.system.2010.06.014

Liu, P. L., Chen, ch. J., \& Chang, Y. J. (2010). Effects of a computer- assisted concept mapping learning strategy on EFL college student's English reading comprehension. Computer and Education, 54, 436-445. http://dx.doi.org/10.1016/j.compedu.2009.08.027

Marzban, A. (2011). Improvement of reading comprehension through computer-assisted language learning in Iranian intermediate EFL students. Procedia Computer Science, 3, 3-10. http://dx.doi.org/10.1016/j.procs.2010.12.003

Rahimi, M., \& Hosseini S. F. (2011). The impact of computer-based activities on Iranian high school students' attitudes towards computer assisted language learning. Procedia Computer Science, 3, 183-190. http://dx.doi.org/10.1016/j.procs.2010.12.031

Rahimi, M., \& Yadollahi, S. (2011). Foreign language learning attitude as a predictor of attitudes towards computer-assisted language learning. Procedia Computer Science, 3, 167-174. http://dx.doi.org/10.1016/j.procs.2010.12.029

Rezvani, E., \& Ketabi, S. (2011). On the effectiveness of using Web-and print-based materials in teaching grammar to Iranian EFL learners. Procedia-Social and Behavioral Sciences, 15, 376-381. http://dx.doi.org/10.1016/j.sbspro.2011.03.105

Sophocleous, S. P. (2012). CALL (computer assisted language learning) wiki. Procedia-Social and Behavioral Sciences, 34, 174-180. http://dx.doi.org/10.1016/j.sbspro.2012.02.035

Uzun, L. (2012). The internet and computer-mediated artefacts for foreign language learning and practice, and intercultural communication: Moodle, second life, and others. Procedia-Social and Behavioral Sciences, 46, 3296-3300. http://dx.doi.org/10.1016/j.sbspro.2012.06.054 